\title{
Low Temperature Synthesis of High Crystalline Spinel Oxides: $\mathrm{LiNi}_{1 / 2} \mathrm{Mn}_{3 / 2} \mathrm{O}_{4}$
}

\author{
Yasuaki MATSUDA, ${ }^{a}, *$ Masaki MATSUI, ${ }^{a, b}$ Takahiro SANDA, ${ }^{a}$ \\ Yusuke TAKASHI, ${ }^{a}$ and Nobuyuki IMANISHI ${ }^{a}$
}

\author{
a Department of Chemistry Mie University, 1577 Kurimamachiya Tsu, Mie 514-8507, Japan \\ b Japan Science and Technology Agency, PRESTO, 4-1-8 Honcho, Kawaguchi, Saitama 332-0012, Japan \\ * Corresponding author: matsuda@chem.mie-u.ac.jp
}

\begin{abstract}
The crystal growth process of $\mathrm{LiNi}_{1 / 2} \mathrm{Mn}_{3 / 2} \mathrm{O}_{4}$ was investigated and the octahedral shaped $\mathrm{LiNi}_{1 / 2} \mathrm{Mn}_{3 / 2} \mathrm{O}_{4}$ was successfully synthesized by a low temperature synthesis. The morphology change was accelerated by the spinelrocksalt phase transformation caused by the oxygen loss. After re-oxidation, high crystalline $\mathrm{LiNi}_{1 / 2} \mathrm{Mn}_{3 / 2} \mathrm{O}_{4} \mathrm{With}$ octahedral morphology was obtained. High crystalline $\mathrm{LiNi}_{1 / 2} \mathrm{Mn}_{3 / 2} \mathrm{O}_{4}$ with the particle size of $1-3 \mu \mathrm{m}$ was obtained by the low temperature synthesis controlling the oxygen partial pressure. High crystalline $\mathrm{LiNi}_{1 / 2} \mathrm{Mn}_{3 / 2} \mathrm{O}_{4}$ crystallized at $850^{\circ} \mathrm{C}$ exhibited an initial charge capacity of $145 \mathrm{mAhg}^{-1}$ and an initial discharge capacity of $137 \mathrm{mAh} \mathrm{g}^{-1}$ with a plateau at $4.7 \mathrm{~V}$, and $90 \%$ of cycle retention after 100 cycles at $60^{\circ} \mathrm{C}$. Microparticulation of high crystalline $\mathrm{LiNi}_{1 / 2} \mathrm{Mn}_{3 / 2} \mathrm{O}_{4}$ enhanced the discharge capacity.
\end{abstract}

(c) The Electrochemical Society of Japan, All rights reserved.

Keywords : Li-ion Battery, Spinel Oxide, Morphology Change, Octahedral-shaped Particle

1. Introduction

Transition metal-substituted manganate spinel materials $\left(\mathrm{Li} M_{x}\right.$ $\mathrm{Mn}_{2-x} \mathrm{O}_{4}, M: \mathrm{Ni}, \mathrm{Cr}, \mathrm{Co}, \mathrm{Fe}$ and $\mathrm{Cu}$ ) have attracted much attentions as positive electrodes for rechargeable $\mathrm{Li}$-ion batteries due to the high-voltage plateaus above $4.5 \mathrm{~V}$ vs. $\mathrm{Li}^{+} / \mathrm{Li}^{1-5}$ Among these materials, $\mathrm{LiNi}_{1 / 2} \mathrm{Mn}_{3 / 2} \mathrm{O}_{4}$ is the most promising material because of its high discharge capacity and dominant plateau at approximately at $4.7 \mathrm{~V}$ coming from the redox process of $\mathrm{Ni}^{2+} / \mathrm{Ni}^{4+}$ together with lithiation and delithiation. ${ }^{4-10}$ However, the biggest problem of this material is the capacity degradation due to the decomposition of the electrolyte.

A significant improvement of the cycle stability was achieved by increasing crystallinity of $\mathrm{LiNi}_{1 / 2} \mathrm{Mn}_{3 / 2} \mathrm{O}_{4}$ with the octahedral morphology. ${ }^{8,9}$ The facets of the (111) surface, which is the most stable surface, cover the largest area of the octahedron and might improve cycle stability. ${ }^{11-13}$ High crystalline $\mathrm{LiNi}_{1 / 2} \mathrm{Mn}_{3 / 2} \mathrm{O}_{4}$ with the octahedral morphology was synthesized by the two-step solidstate reaction and the morphology of $\mathrm{LiNi}_{1 / 2} \mathrm{Mn}_{3 / 2} \mathrm{O}_{4}$ changed with the pre-sintering temperature. ${ }^{8,9} \mathrm{We}$ also confirmed that the cycle retention of the high crystalline $\mathrm{LiNi}_{1 / 2} \mathrm{Mn}_{3 / 2} \mathrm{O}_{4}$ with octahedral shape was more than $90 \%$ after 100 cycles at $60^{\circ} \mathrm{C}$. For the improvement of the power density, the decrease of the particle size of the octahedral $\mathrm{LiNi}_{1 / 2} \mathrm{Mn}_{3 / 2} \mathrm{O}_{4}$ would be required. If low temperature synthesis is possible, it is favorable to obtain high crystalline $\mathrm{LiNi}_{1 / 2} \mathrm{Mn}_{3 / 2} \mathrm{O}_{4}$ with small particle size. However, the formation mechanism of high crystalline spinel oxides has not been well understood yet.

Therefore, we investigated the crystal growth process of $\mathrm{LiNi}_{1 / 2} \mathrm{Mn}_{3 / 2} \mathrm{O}_{4}$ using high temperature X-ray diffraction (H.T.$\mathrm{XRD})$, scanning electron microscopy (SEM) and thermo gravimetric (TG) analysis and the octahedral shaped $\mathrm{LiNi}_{1 / 2} \mathrm{Mn}_{3 / 2} \mathrm{O}_{4}$ with small particle size was successfully synthesized at low temperature. In this study, the crystal growth mechanism and the electrochemical properties of the high crystalline $\mathrm{LiNi}_{1 / 2} \mathrm{Mn}_{3 / 2} \mathrm{O}_{4}$ with different particle size were discussed.

\section{Experimental}

High crystalline $\mathrm{LiNi}_{1 / 2} \mathrm{Mn}_{3 / 2} \mathrm{O}_{4}$ was synthesized by the twostep solid-state method to study the crystal growth process of $\mathrm{LiNi}_{1 / 2} \mathrm{Mn}_{3 / 2} \mathrm{O}_{4}{ }^{8,9}$ A nickel manganese double hydroxide (Ni:Mn = 0.99:3.01) synthesized by a coprecipitation method was annealed at $500^{\circ} \mathrm{C}$ for $8 \mathrm{~h}$. The obtained complex oxide was mixed with stoichiometric amount of $\mathrm{LiOH} \cdot \mathrm{H}_{2} \mathrm{O}(98 \%$, Kanto Chemical, Japan) and calcined at $1000^{\circ} \mathrm{C}$ for $10 \mathrm{~h}$ in air and subsequently re-oxidized at $700^{\circ} \mathrm{C}$ for $24 \mathrm{~h}, 650^{\circ} \mathrm{C}$ for $24 \mathrm{~h}$ and $600^{\circ} \mathrm{C}$ for $48 \mathrm{~h}$ with a heating rate of $5 \mathrm{~K} \mathrm{~min}^{-1}$ and cooling rate of $1 \mathrm{~K} \mathrm{~min}^{-1}$. To decrease the particle size of high crystalline $\mathrm{LiNi}_{1 / 2} \mathrm{Mn}_{3 / 2} \mathrm{O}_{4}$, low temperature synthesis was applied based on the hypothesis of the crystal growth process. Low temperature synthesis of the morphology controlled $\mathrm{LiNi}_{1 / 2} \mathrm{Mn}_{3 / 2} \mathrm{O}_{4}$ was performed using $\mathrm{LiNi}_{1 / 2} \mathrm{Mn}_{3 / 2} \mathrm{O}_{4}$ synthesized at $800^{\circ} \mathrm{C}$ for $10 \mathrm{~h}$ as a starting material. $\mathrm{LiNi}_{1 / 2} \mathrm{Mn}_{3 / 2} \mathrm{O}_{4}$ was reduced in a $\mathrm{N}_{2}$ gas flow at $850^{\circ} \mathrm{C}$ for $3 \mathrm{~h}$ and then re-oxidized at $850^{\circ} \mathrm{C}$ for $3 \mathrm{~h}, 700^{\circ} \mathrm{C}$ for $24 \mathrm{~h}, 650^{\circ} \mathrm{C}$ for $24 \mathrm{~h}$ and $600^{\circ} \mathrm{C}$ for $48 \mathrm{~h}$ in an $\mathrm{O}_{2}$ gas flow with a heating rate of $5 \mathrm{~K} \mathrm{~min}^{-1}$ and cooling rate of $1 \mathrm{~K} \min ^{-1}$.

A powder X-ray diffractometer (RINT 2500, Rigaku, with $\mathrm{CuK \alpha}$ radiation) equipped with a high temperature furnace attachment was employed for the H.T.-XRD measurements to study the phase transformation of $\mathrm{LiNi}_{1 / 2} \mathrm{Mn}_{3 / 2} \mathrm{O}_{4}$ during the two-step solid-state reaction. Mixed powder of complex oxide and $\mathrm{LiOH} \cdot \mathrm{H}_{2} \mathrm{O}$ was set at the equipment and H.T.-XRD data were taken in order to see the phase change during the heating and cooling processes between $25^{\circ} \mathrm{C}$ and $1000^{\circ} \mathrm{C}$, time change of the phase at $1000^{\circ} \mathrm{C}$ and reoxidation processes at $700^{\circ} \mathrm{C}$. Morphology change of $\mathrm{LiNi}_{1 / 2^{-}}$ $\mathrm{Mn}_{3 / 2} \mathrm{O}_{4}$ particles was observed by using scanning electron microscopy (SEM; S-4000, Hitachi). TG analysis (Thermo Plus TG 8120, Rigaku) was employed to measure the mass change in air and a $\mathrm{N}_{2}$ gas flow. Elemental analysis for $\mathrm{Li}, \mathrm{Ni}$ and $\mathrm{Mn}$ in $\mathrm{LiNi}_{1 / 2} \mathrm{Mn}_{3 / 2} \mathrm{O}_{4}$ was conducted by using inductively coupled plasma spectroscopy (ICP-OES; Agilent Technologies ICP-OES 710). Surface area of morphology controlled $\mathrm{LiNi}_{1 / 2} \mathrm{Mn}_{3 / 2} \mathrm{O}_{4}$ was measured by the surface area and porosity analyzer (TriStar II, Micromeritics). 

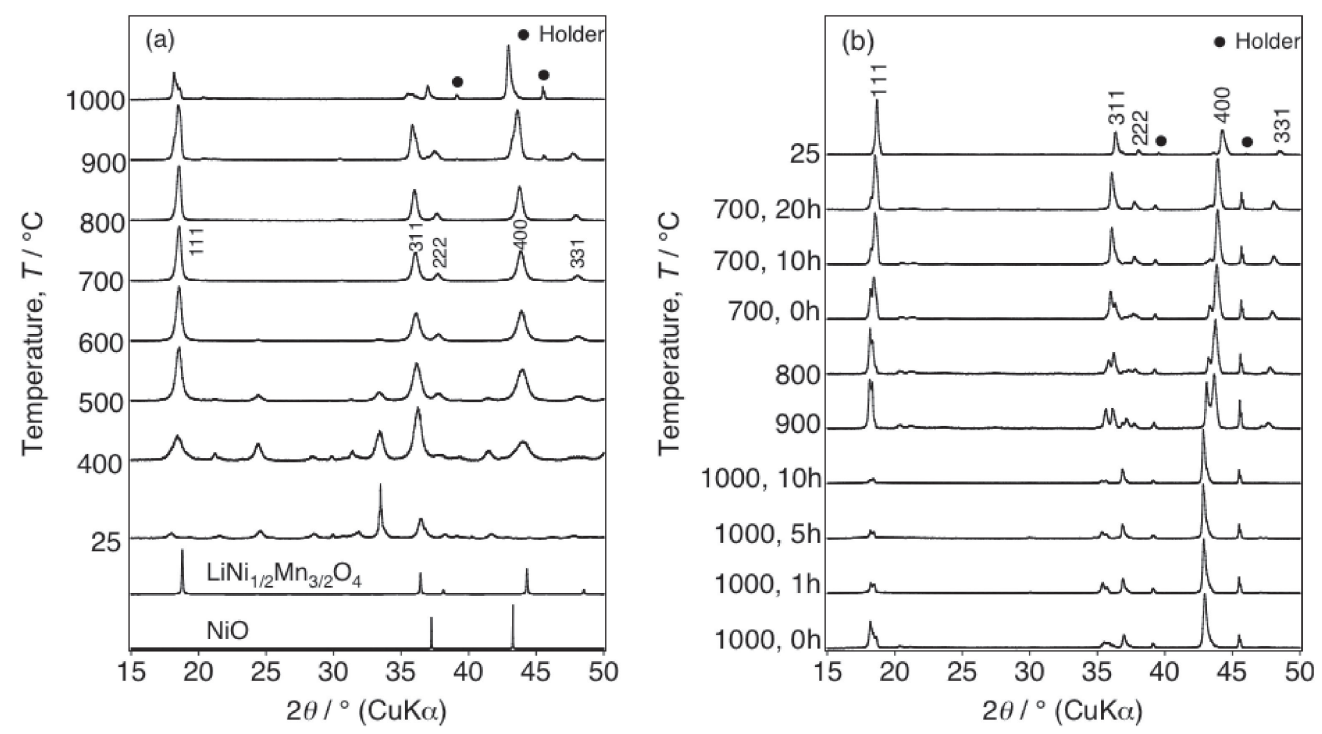

Figure 1. H.T.-XRD patterns for $\mathrm{LiNi}_{1 / 2} \mathrm{Mn}_{3 / 2} \mathrm{O}_{4}$ during (a) heating process and (b) cooling process.
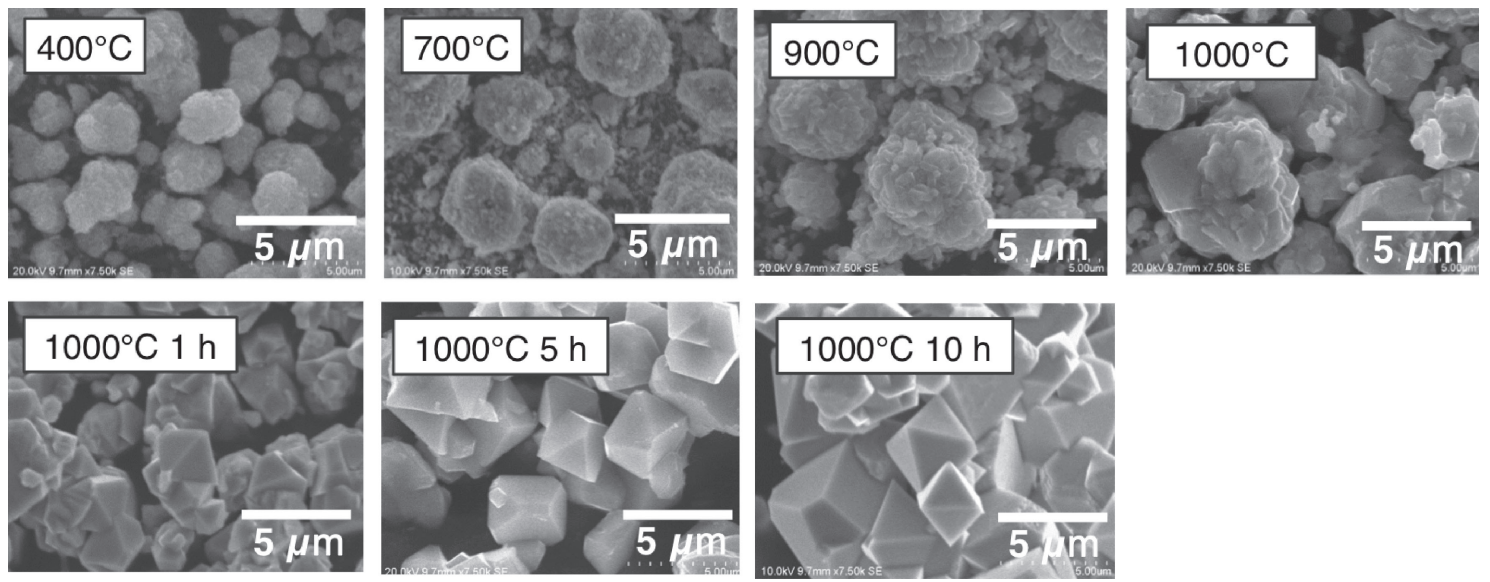

Figure 2. $\mathrm{SEM}$ images of $\mathrm{LiNi}_{1 / 2} \mathrm{Mn}_{3 / 2} \mathrm{O}_{4}$ during morphology changing process.

Galvanostatic charging-discharging tests were performed using a two-electrode cell (TJ-AC, Tomcell Japan). The cathode material consisted of the active material, acetylene black (AB) and polyvinylidene fluoride (PVDF) at a gravimetric ratio of 80:10:10. The anode was metallic lithium. The electrolyte was $1 \mathrm{M} \mathrm{LiPF}_{6}$ dissolved in ethylene cabonate (EC) and dimethyl carbonate (DMC) (1:1 vol.\%). Charge-discharge measurements were carried out in the range of $3.0-5.1 \mathrm{~V}$ vs. $\mathrm{Li} / \mathrm{Li}$ at $60^{\circ} \mathrm{C}$ and at a charge/discharge rate of $1 \mathrm{C}\left(1 \mathrm{C}=147 \mathrm{mAh} \mathrm{g}^{-1}\right)$.

\section{Result and Discussion}

Figure 1 shows H.T.-XRD patterns for $\mathrm{LiNi}_{1 / 2} \mathrm{Mn}_{3 / 2} \mathrm{O}_{4}$ during (a) heating process and (b) cooling process. Diffraction peaks which could be indexed with the spinel structure were observed at $400^{\circ} \mathrm{C}$ and the formation of the spinel phase proceeded up to $800^{\circ} \mathrm{C}^{4,8,14}$ The decrease of the peak intensity of the spinel phase and formation of the $\mathrm{NiO}$ like rocksalt phase began to occur above $900^{\circ} \mathrm{C}$ and the rocksalt phase became dominant at $1000^{\circ} \mathrm{C}$. During the cooling step, the spinel phase was reformed and the rocksalt phase disappeared after sintering at $700^{\circ} \mathrm{C}$ for $20 \mathrm{~h}$. Reversible phase transformation from the spinel to the $\mathrm{NiO}$ like rocksalt phase above $700^{\circ} \mathrm{C}$ in air was in good agreement with the previous reports. ${ }^{15,16}$

Figure 2 shows $\mathrm{SEM}$ images of $\mathrm{LiNi}_{1 / 2} \mathrm{Mn}_{3 / 2} \mathrm{O}_{4}$ during morphology changing process. The morphology of the particle didn't show no significant change at $700^{\circ} \mathrm{C}$ and a slight growth of the

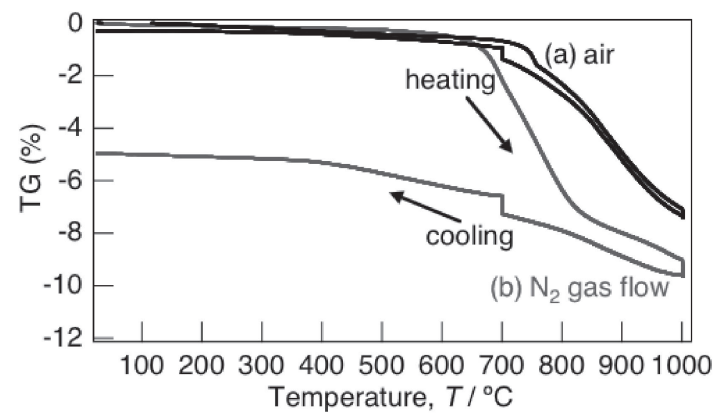

Figure 3. TG curves of $\mathrm{LiNi}_{1 / 2} \mathrm{Mn}_{3 / 2} \mathrm{O}_{4}$ measured in (a) air and (b) $\mathrm{N}_{2}$ gas flows with a heating rate of $5 \mathrm{~K} \mathrm{~min}^{-1}$ and cooling rate of $1 \mathrm{~K} \mathrm{~min}^{-1}$. The samples were kept at $1000^{\circ} \mathrm{C}$ for $5 \mathrm{~h}$ and $700^{\circ} \mathrm{C}$ for $3 \mathrm{~h}$ at cooling process.

primary particles was observed at $900^{\circ} \mathrm{C}$. A drastic morphology change was observed at $1000^{\circ} \mathrm{C}$ and the octahedral-shaped particles were observed after $5 \mathrm{~h}$. This indicates the spinel-rocksalt phase transformation enhanced the morphology change.

Figure 3 shows TG curves of $\mathrm{LiNi}_{1 / 2} \mathrm{Mn}_{3 / 2} \mathrm{O}_{4}$ measured in (a) air and (b) $\mathrm{N}_{2}$ gas flows. Weight loss started at $750^{\circ} \mathrm{C}$ and reached about $8 \mathrm{wt} \%$ at $1000^{\circ} \mathrm{C}$ in air. The TG curve in air exhibited the good reversibility between cooling and heating process. On the other hand, TG curve under the $\mathrm{N}_{2}$ gas flow showed that the weight loss 


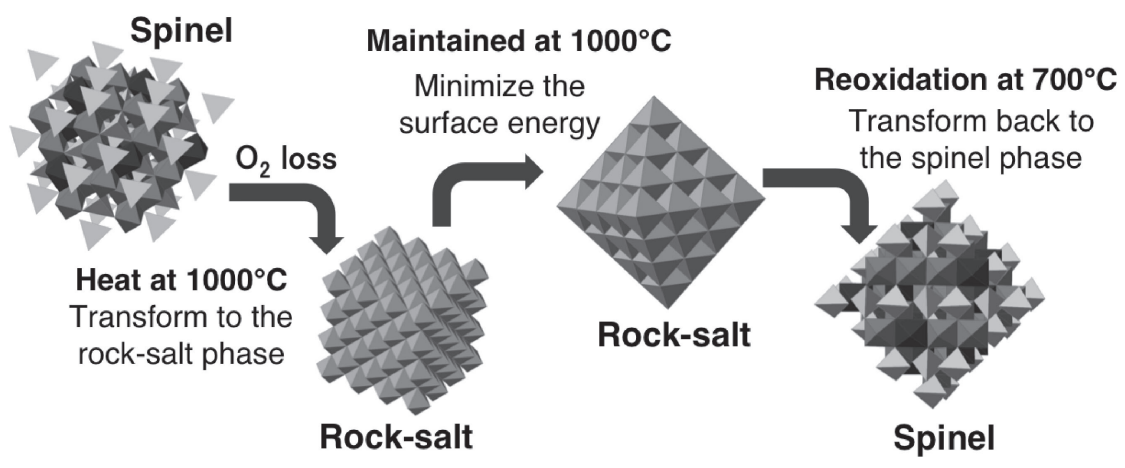

Figure 4. A schematic drawing of the morphology change process of $\mathrm{LiNi}_{1 / 2} \mathrm{Mn}_{3 / 2} \mathrm{O}_{4}$.

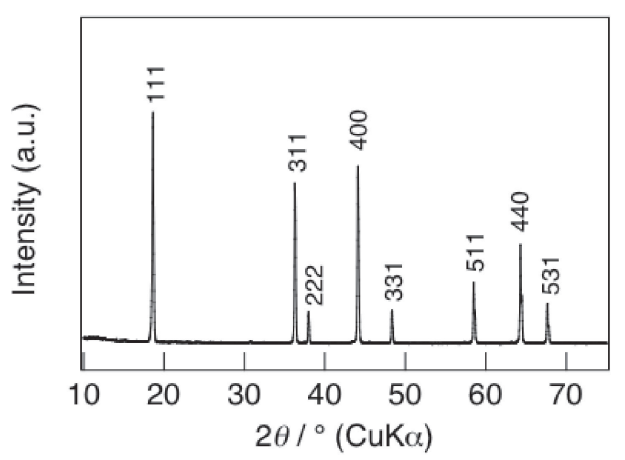

Figure 5. XRD pattern for high crystalline $\mathrm{LiNi}_{1 / 2} \mathrm{Mn}_{3 / 2} \mathrm{O}_{4}$ synthesized at $850^{\circ} \mathrm{C}$ by changing synthesis atmosphere.

occurred at $650^{\circ} \mathrm{C}$ and poor reversibility was observed between heating and cooling processes. This suggests the existing of correlation between the reversible phase transitions and the oxygen content in the material process at high temperature.

Figure 4 shows a schematic drawing of the morphology change process of $\mathrm{LiNi}_{1 / 2} \mathrm{Mn}_{3 / 2} \mathrm{O}_{4}$. The morphology change was accelerated by the phase transformation to the rocksalt phase. The phase transformation to the rocksalt phase indicates that the diffusion process of $\mathrm{Ni}$ or $\mathrm{Mn}$ was accelerated resulting in the significant morphology change. And TG analysis proved the correlation between the reversible phase transformation and the oxygen loss process at high temperature. In addition, the surface energy of the particles should be minimized during the particle growth process. As a consequence, the morphology of the particle transformed to the octahedral shape, whose surface consists of the oxygen closed packed layer.

Since phase transformation of $\mathrm{LiNi}_{1 / 2} \mathrm{Mn}_{3 / 2} \mathrm{O}_{4}$ to rocksalt structure related to the oxygen loss, the temperature of the phase transition should be affected by oxygen partial pressure. We attempted the low temperature synthesis of octahedral shaped $\mathrm{LiNi}_{1 / 2} \mathrm{Mn}_{3 / 2} \mathrm{O}_{4}$ by changing the synthesis atmosphere based on this hypothesis. $\mathrm{LiNi}_{1 / 2} \mathrm{Mn}_{3 / 2} \mathrm{O}_{4}$ reduced under the $\mathrm{N}_{2}$ gas flow at $850^{\circ} \mathrm{C}$ for $3 \mathrm{~h}$, where the well-crystallized particles are expected to be obtained, and then re-oxidized by changing the atmosphere to an oxygen gas flow. Figure 5 shows XRD pattern for $\mathrm{LiNi}_{1 / 2} \mathrm{Mn}_{3 / 2} \mathrm{O}_{4}$ crystallized at $850^{\circ} \mathrm{C}$. All diffraction peaks were assigned to the spinel structure with a lattice constant of $8.17 \AA$, which is comparable to that of $\mathrm{LiNi}_{1 / 2} \mathrm{Mn}_{3 / 2} \mathrm{O}_{4}$ crystallized at $1000^{\circ} \mathrm{C}$. The atomic ratio of $\mathrm{Li} / \mathrm{Ni} / \mathrm{Mn}$ in morphology controlled $\mathrm{LiNi}_{1 / 2} \mathrm{Mn}_{3 / 2} \mathrm{O}_{4}$ was $0.99 / 0.48 / 1.5$ where the ratio was normalized according to $\mathrm{Mn}$ at 1.5 , which showed no composition change of cations during the morphology change. No difference of the atomic ratio of $\mathrm{Li} / \mathrm{Ni} / \mathrm{Mn}$ was observed for high crystalline $\mathrm{LiNi}_{1 / 2} \mathrm{Mn}_{3 / 2} \mathrm{O}_{4}$ synthesized at different temperatures. Figure 6 shows $\mathrm{SEM}$ images of $\mathrm{LiNi}_{1 / 2^{-}}$ $\mathrm{Mn}_{3 / 2} \mathrm{O}_{4}$ particles crystallized at $850^{\circ} \mathrm{C}$. Octahedral-shaped particles

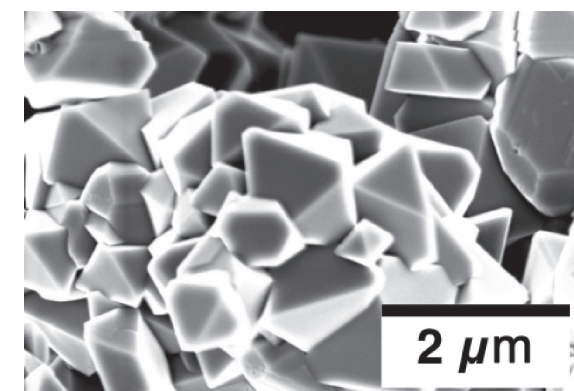

Figure 6. SEM image of high crystalline $\mathrm{LiNi}_{1 / 2} \mathrm{Mn}_{3 / 2} \mathrm{O}_{4}$ crystallized at $850^{\circ} \mathrm{C}$.

with the particle size of $1-3 \mu \mathrm{m}$ were observed, which was smaller than those with the particle size of $5 \mu \mathrm{m}$ crystallized at $1000^{\circ} \mathrm{C}$ in air. The surface area of the morphology controlled $\mathrm{LiNi}_{1 / 2} \mathrm{Mn}_{3 / 2} \mathrm{O}_{4}$ increased from 4.648 to $5.428 \mathrm{~m}^{2} \mathrm{~g}^{-1}$ by the low temperature synthesis, which is in good agreement with the particle size change. By changing the synthesis atmosphere, we were able to successfully control the particle size of the high crystalline $\mathrm{LiNi}_{1 / 2} \mathrm{Mn}_{3 / 2} \mathrm{O}_{4}$.

Figure 7 shows charge-discharge profiles of high crystalline $\mathrm{LiNi}_{1 / 2} \mathrm{Mn}_{3 / 2} \mathrm{O}_{4}$ crystallized at $850^{\circ} \mathrm{C}$ (a), at $1000^{\circ} \mathrm{C}$ (b) and the comparison of cycle performance at a charge/discharge rate of $1 \mathrm{C}$ with a voltage range $3.0-5.1 \mathrm{~V}$ at $60^{\circ} \mathrm{C}$ (c). The high crystalline $\mathrm{LiNi}_{1 / 2} \mathrm{Mn}_{3 / 2} \mathrm{O}_{4}$ synthesized at $850^{\circ} \mathrm{C}$ exhibited an initial charge capacity of $145 \mathrm{mAhg}^{-1}$ and an initial discharge capacity of $137 \mathrm{mAh} \mathrm{g}^{-1}$ with a plateau at $4.7 \mathrm{~V}$ attributed to the $\mathrm{Ni}^{2+} / \mathrm{Ni}^{4+}$ redox couple. ${ }^{8,10}$ Charge-discharge profiles were similar to those of $\mathrm{LiNi}_{1 / 2} \mathrm{Mn}_{3 / 2} \mathrm{O}_{4}$ with $\mathrm{Ni}^{2+}$ and $\mathrm{Mn}^{4+}$ ordered structure. ${ }^{15-17}$ The discharge capacity of $122 \mathrm{mAh} \mathrm{g}^{-1}$ was maintained after 100 cycles. On the other hand, high crystalline $\mathrm{LiNi}_{1 / 2} \mathrm{Mn}_{3 / 2} \mathrm{O}_{4}$ synthesized at $1000^{\circ} \mathrm{C}$ showed the discharge capacity of $122 \mathrm{mAh} \mathrm{g}^{-1}$ at initial cycle and $118 \mathrm{mAh} \mathrm{g}^{-1}$ after 100 cycles. Both octahedral shaped $\mathrm{LiNi}_{1 / 2} \mathrm{Mn}_{3 / 2} \mathrm{O}_{4}$ exhibit excellent capacity retention. The high crystalline $\mathrm{LiNi}_{1 / 2} \mathrm{Mn}_{3 / 2} \mathrm{O}_{4}$ synthesized at low temperature showed higher discharge capacity during 100 cycles. Coulombic efficiencies of high crystalline $\mathrm{LiNi}_{1 / 2} \mathrm{Mn}_{3 / 2} \mathrm{O}_{4}$ samples were summarized in Table 1. Both high crystalline $\mathrm{LiNi}_{1 / 2} \mathrm{Mn}_{3 / 2} \mathrm{O}_{4}$ samples exhibited low coulombic efficiency at an initial charge/discharge cycle, which might be related to the electrolyte decomposition reaction at the initial charge process. High crystalline $\mathrm{LiNi}_{1 / 2} \mathrm{Mn}_{3 / 2} \mathrm{O}_{4}$ synthesized at $1000^{\circ} \mathrm{C}$ exhibited $90 \%$ coulombic efficiency after 10 cycles. In contrast, $\mathrm{LiNi}_{1 / 2} \mathrm{Mn}_{3 / 2} \mathrm{O}_{4}$ crystallized at $850^{\circ} \mathrm{C}$ showed $93 \%$ coulombic efficiency after 10 cycles. Micronization of high crystalline $\mathrm{LiNi}_{1 / 2} \mathrm{Mn}_{3 / 2} \mathrm{O}_{4}$ might lead to an improvement of the kinetic performance by reducing the transport distance for lithiumions, which decreases ohmic polarization loss due to lithium-ion migration. The decrease of the ohmic polarization loss should be affected for the enhancement of the coulombic efficiency of high crystalline $\mathrm{LiNi}_{1 / 2} \mathrm{Mn}_{3 / 2} \mathrm{O}_{4}$. Our research confirmed the importance 

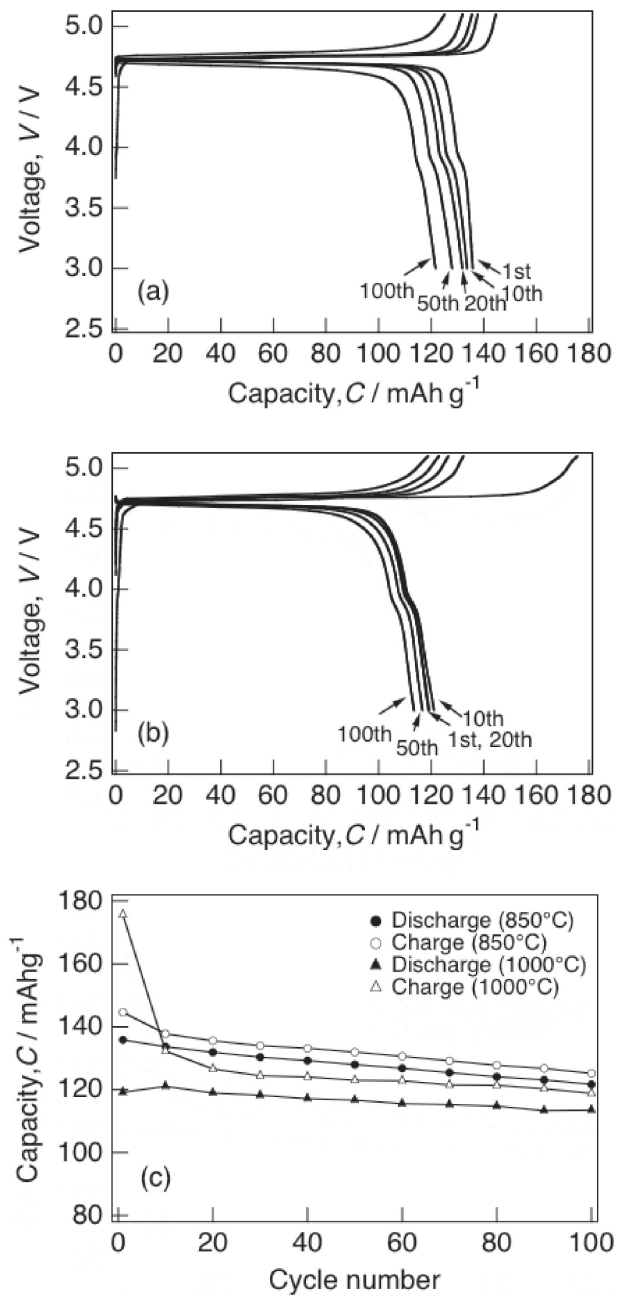

Figure 7. Charge-discharge profiles of high crystalline $\mathrm{LiNi}_{1 / 2^{-}}$ $\mathrm{Mn}_{3 / 2} \mathrm{O}_{4}$ crystallized at $850^{\circ} \mathrm{C}$ (a), at $1000^{\circ} \mathrm{C}$ (b), and comparison of cycle performances of high crystalline $\mathrm{LiNi}_{1 / 2} \mathrm{Mn}_{3 / 2} \mathrm{O}_{4}$ at a charge/ discharge rate of $1 \mathrm{C}$ with a voltage range $3.0-5.1 \mathrm{~V}$ at $60^{\circ} \mathrm{C}$ (c).

of the particle size control of high crystalline $\mathrm{LiNi}_{1 / 2} \mathrm{Mn}_{3 / 2} \mathrm{O}_{4}$. Further investigation is needed for the understanding of the details of the relationship between the particle size and electrochemical properties of high crystalline $\mathrm{LiNi}_{1 / 2} \mathrm{Mn}_{3 / 2} \mathrm{O}_{4}$.

\section{Conclusion}

We investigated morphology change process of $\mathrm{LiNi}_{1 / 2} \mathrm{Mn}_{3 / 2} \mathrm{O}_{4}$. The morphology change was accelerated by the spinel/rocksalt phase transformation caused by the oxygen loss. We successfully
Table 1. Coulombic efficiencies of high crystalline $\mathrm{LiNi}_{1 / 2^{-}}$ $\mathrm{Mn}_{3 / 2} \mathrm{O}_{4}$.

\begin{tabular}{ccc}
\hline \multirow{2}{*}{ Cycle number } & \multicolumn{2}{c}{ Coulombic efficiency (\%) } \\
\cline { 2 - 3 } & Crystallized at $1000^{\circ} \mathrm{C}$ & Crystallized at $850^{\circ} \mathrm{C}$ \\
\hline 1 & 65.24 & 77.26 \\
2 & 84.25 & 82.84 \\
10 & 89.93 & 94.00 \\
20 & 86.22 & 93.98 \\
50 & 90.41 & 93.41 \\
100 & 90.27 & 92.21 \\
\hline
\end{tabular}

decreased particle size of the high crystalline $\mathrm{LiNi}_{1 / 2} \mathrm{Mn}_{3 / 2} \mathrm{O}_{4}$ with octahedral shape by the low temperature synthesis controlling the oxygen partial pressure. Particle size of the octahedral shaped $\mathrm{LiNi}_{1 / 2} \mathrm{Mn}_{3 / 2} \mathrm{O}_{4}$ decreased from $5 \mu \mathrm{m}$ to $1-3 \mu \mathrm{m}$. High crystalline $\mathrm{LiNi}_{1 / 2} \mathrm{Mn}_{3 / 2} \mathrm{O}_{4}$ crystallized at $850^{\circ} \mathrm{C}$ exhibited an initial charge capacity of $145 \mathrm{mAhg}^{-1}$ and an initial discharge capacity of $137 \mathrm{mAh} \mathrm{g}^{-1}$ with a plateau at $4.7 \mathrm{~V}$, and $90 \%$ of cycle retention after 100 cycles at $60^{\circ} \mathrm{C}$. Higher discharge capacity was observed by microparticulation of high crystalline $\mathrm{LiNi}_{1 / 2} \mathrm{Mn}_{3 / 2} \mathrm{O}_{4}$.

\section{References}

1. K. Amine, H. Tsukamoto, H. Yasuda, and Y. Fujita, J. Power Sources, 68, 604 (1997).

2. Q. Zhong, A. Bonakdarpour, M. Zhang, Y. Gao, and J. Dahn, J. Electrochem. Soc., 144, 205 (1997).

3. H. Kawai, M. Nagata, H. Tsukamoto, and A. R. West, Electrochim. Acta, 45, 315 (1999).

4. J.-H. Kim, S.-T. Myung, C. S. Yoon, S. G. Kang, and Y.-K. Sun, Chem. Mater, 16, 906 (2004).

5. T. Ohzuku, S. Takeda, and M. Iwanaga, J. Power Sources, 81-82, 90 (1999).

6. M. Kunduraci and G.-G. Amatucc, J. Power Sources, 165, 359 (2007).

7. G. Liu, K.-S. Park, J. Song, and J.-B. Goodenough, J. Power Sources, 243, 260 (2013).

8. T. Ohzuku, K. Ariyoshi, S. Yamamoto, and Y. Makimura, Chem. Lett., 30, 1270 (2001).

9. K. Ariyoshi, Y. Maeda, T. Kawai, and T. Ohzuku, J. Electrochem. Soc., 158, A281 (2011).

10. Y. Terada, K. Yasaka, F. Nishikawa, T. Konishi, M. Yoshio, and I. Nakai, J. Solid State Chem., 156, 286 (2001)

11. M. Nakayama, H. Taki, T. Nakamura, S. Tokuda, R. Jalem, and T. Kasuga, J. Phys. Chem. C, 118, 27245 (2014).

12. A. Karim, S. Fosse, and K.-A. Persson, Phys. Rev. B, 87, 075332 (2013).

13. M. Hirayama, H. Ido, K. Kim, W. Cho, K. Tamura, J. Mizuki, and R. Kanno, J. Am. Chem. Soc., 132, 15268 (2010).

14. Y. Idemoto, H. Narai, and N. Koura, J. Power Sources, 125, 119 (2003).

15. J. Song, D.-W. Shin, Y. Lu, C.-D. Amos, A. Manthiram, and J.-B. Goodenough, Chem. Mater, 24, 3101 (2012).

16. L. Wang, H. Li, X. Huang, and E. Baudrin, Solid State Ionics, 193, 32 (2011).

17. K. Amine, H. Tukamoto, H. Yasuda, and Y. Fujita, J. Electrochem. Soc., 143, 1607 (1996). 